UDC 504.75.05

\title{
MONITORING ACTIVITY OF THE CO 2 EMISSION OBJECTS SYSTEM COMPONENTS IN FORMATION OF THE AIR MASS IN INDIVIDUAL CLOSED PREMISES
}

\author{
Storozhenko Dmytro ${ }^{1}$, Dryuchko Oleksandr ${ }^{2 *}$, Golik Yuri ${ }^{3}$, Kytaihora Kateryna $^{4}$, \\ Gornitsky Igor ${ }^{5}$, Misko Anton ${ }^{6}$ \\ ${ }^{1}$ Poltava National Technical Yuri Kondratyuk University https://orcid.org/0000-0001-7920-5161 \\ ${ }^{2}$ Poltava National Technical Yuri Kondratyuk University https://orcid.org/0000-0002-2157-0526 \\ ${ }^{3}$ Poltava National Technical Yuri Kondratyuk University https://orcid.org/0000-0002-6346-5484 \\ ${ }^{4}$.Southwest Jiaotong University (Chengdu, China) https://orcid.org/0000-0002-3752-0865 \\ ${ }^{5}$ Poltava Quartz Glass Plant (Ukraine) https://orcid.org/0000-0002-6930-5203 \\ ${ }^{6}$ Poltava Quartz Glass Plant (Ukraine) https://orcid.org/0000-0002-5372-1536 \\ *Corresponding author E-mail: dog.chemistry@gmail.com
}

According to the developed methodology of the experiment and with the use of electronic devices for measuring the content of carbon dioxide $\left(\mathrm{CO}_{2}\right)$ in the air and using a set of special laboratory tools, the following were studied on the example of a school audience: a) the variety of interactions of the external environment and the subsystem - classroom air; b) the activity of constituent internal objects (present students, plants, absorbent surfaces of structural elements and the interior) in release and absorption of $\mathrm{CO}_{2}$, depending on conditions and variation in the action of dominant factors; $c$ ) their manifestation and influence on forming the composition and content of the air mass, and therefore the internal microclimate of the classroom, which quality directly affects the health and performance of the present people.

Keywords: room air, $\mathrm{CO}_{2}$ emission sources, $\mathrm{CO}_{2}$ concentration, adaptive microclimate support systems

\section{МОНІТОРИНГ АКТИВНОСТІ КОМПОНЕНТІВ СИСТЕМИ ОБ'ЄКТІВ ЕМІСІЇ СО ПРИ ФОРМУВАННІ ПОВІТРЯНОЇ МАСИ ОКРЕМИХ ПРИМІЩЕНЬ}

\author{
Стороженко Д.О. ${ }^{1}$, Дрючко О.Г. ${ }^{*}$, Голік Ю.С. ${ }^{3}$, Китайгора К.О., \\ Горницький I.O.5, Мисько А.Ю. ${ }^{6}$ \\ 1, 2,3 Національний університет «Полтаська політехніка імені Юрія Кондратюка» \\ ${ }^{4}$ Південно-західний університет Цзяотун, Ченду, Китай \\ 5, 6 Полтавський завод кварцового скла \\ *Адреса для листування E-mail: dog.chemistry@gmail.com
}

\begin{abstract}
Дослідження спрямоване на моніторинг і оцінювання внеску, з'ясування співвідношення обємів кожного окремого джерела емісії $\mathrm{CO}_{2}$ у загальному масо-газо прояві та пошук інноваційних рішень для створення адаптивних систем стабілізації і підтримування мікроклімату в аналогічних об'єктах. Підібрані оптимальні режими функціонування вентиляційних засобів. Встановлено вклад $\mathrm{CO}_{2}$ від життєдіяльності рослин у повітря замкнутої аудиторії у стадіях «фотосинтезу» і «затемнення»; їх активність під впливом дії низки факторів. Виявлена доцільність використання поризованих алюмосилікатних адсорбуючих матеріалів в каналах припливного і рециркуляційного повітря адаптивних систем забезпечення мікроклімату зі змінною витратою повітря і періодичною роботою, з циклічним тепловим реверсом в наслідок прояву ними повторюваності і відтворюваності адсорбуючої здатності у релаксаційних перетвореннях, вузькості гістерезисних залежностей, можливості легкого в енергетичному відношенні реверсуванні напряму перетворень (навіть з використанням малопотужних засобів відновлювальних джерел енергії, НВЧ обробкою), що забезпечить надійність, стабільність роботи і відтворюваність технічних характеристик впроваджених систем.
\end{abstract}

Ключові слова: повітря приміщення, джерела емісії $\mathrm{CO}_{2}$, концентрація $\mathrm{CO}_{2}$, адаптивні системи підтримування мікроклімату 


\section{Introduction}

This work is devoted to the academic problem of continuously searching ways to maintain balance and a compromise between the air quality in the rooms and energy efficiency of the technical systems that provide it.

Indoor air, mainly due to ventilation, can be ideally provided with $\mathrm{CO}_{2}$ content like that in the supply air. However, this is only true if there are no $\mathrm{CO}_{2}$ sources or sinks in the room. The main $\mathrm{CO}_{2}$ source in a room is usually people. It's content depends on the people amount, their job characteristics and the ventilation work intensity in the room. In the closed premises environment, some amount of $\mathrm{CO}_{2}$ also reacts to humidity in atmospheric air with formation of carbonic acid. The room air composition is influenced by the present plants life processes, which, as a result of photosynthesis from carbon dioxide and water form oxygen under the solar radiation action in the chlorophyll presence as a catalyst, as well as organic compounds (mainly carbohydrates),. Carbon dioxide absorbers are adsorbing porous surfaces of brickwork, partition and another parts of interior.

\section{Review of the research sources and publications}

Allocations formed mainly as a result of active people's activity inside the building, are quantified in compliance with the international standard requirements [1], and, being a variable value, necessitate the introduction of automatic air flow rate change in the premises, regulation of its composition, rational use of electricity and, ultimately, the ability to reduce operating costs. And since indoors carbon dioxide level is one of the main criteria for the people presence in room, it is based on the design of adaptive ventilation systems with $\mathrm{CO}_{2}$ control (DCV) [2].

The systems (DCVs) cover all of the above problems and permit them to be solved totally. Their implementation requires a thorough and proper consideration of the behavior, activity and each component's role in the system involved in the $\mathrm{CO}_{2}$ emission processes or participating in its redistribution. The existing generalized information in these fields mainly relates to time-limited study [3], often limited in scope, for example, novelties could not spread and pass efficiency testing (one of them is implementation of forming composite photocatalytically active materials methods based on $\mathrm{TiO}_{2}$ in integrated air purification systems created by aggregate principle [4-7], etc.) or obtained on the basis of some leading manufacturers' closed research protocols.

The authors' research performed on the example of air study in a classroom of an educational institution was aimed at obtaining a comprehensive picture, trend detection, identifying objective features and regularities of heat and mass transfer transformations in such thermodynamically complex interrelated objects.

\section{Definition of unsolved aspects of the problem}

The analysis of the experience gained [8-11] shows that the academic problem solution is only possible with the use of integrated inflow air supply self-adjusting systems $[12,13]$ with the additional inflow and exhaust ducts arrangement with cut-off valves, simultaneous air flows purification and implementation of continuous monitoring systems and object management. [3].

In such systems, the incoming inlet air volume and its quality are determined by the gas composition indices, the indoor circulation mode [1], which primarily determine the functioning efficiency of continuously operating ventilation system. It is clear that the real load on the heating, ventilation and air conditioning systems inside the building differ in different parts of the building, changing over time.

And developing specific projects of the above systems is accompanied by the development of models corresponding to the composition and functioning features of the respective objects (as an example, see Fig. 1 [14]), to the technical means used to reproduce acceptable operation modes. The parameters and modes choice of technical equipment operation is carried out in accordance with the regulatory documents requirements [8-11], which have now become national standards in all countries, for typical service areas types -4 categories of indoor air quality: from IDA 1 - high quality to IDA 4 - low quality.

There are two ways to determine the required air exchange indoors [8-11] - based on specific air exchange rates and based on the permissible pollutants concentrations calculating. In the first case, the required air quality is obtained due to supplying a certain outside air amount to the room, depending on the room purpose and its operation mode; in the second case, depending on the pollutants size and their characteristics in the room.

From the analysis of the normative requirements for the indoor air quality according to the above mentioned standards, it is also evident that in the first category rooms, both with high and low pollution, the ventilation with untreated outside air is problematic. The way out is to use carbon dioxide adsorbers in ambient or recirculating air flows.

In most cases, the intake ducts of modern systems do not provide for gaseous impurities removal, but only filters for mechanical impurities removal are used; in special cases air purification is implemented, mainly with activated charcoal $[15,16]$. In the existing developments variants, due to the complexity and versatility of the studied processes, the lack of properly formed approaches and generalizations in their understanding, there is insufficient thoroughness in justifying the choice of sorbent materials (regarding their functionality degree, the characteristics set choice, technical capabilities and application fields); the concentration effect of gaseous impurities of organic and inorganic nature in the fresh-air intake places is not taken into account [17], etc. 


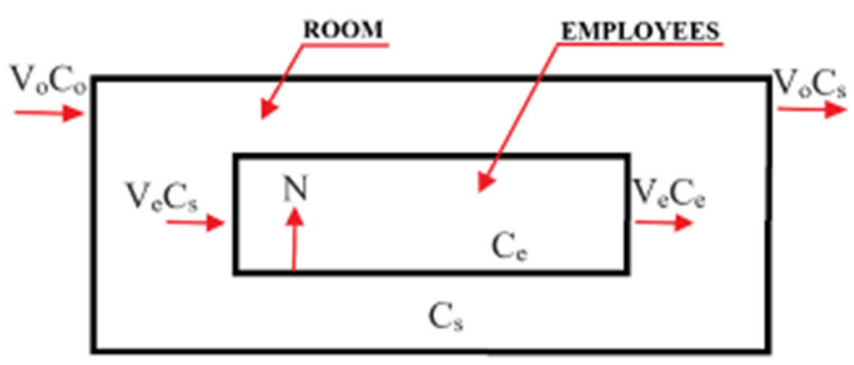

Figure 1 - Two-chamber system model for calculating inlet air flow [14]

An analytical signal for regulating air exchange in such adaptive systems is the carbon dioxide concentration value measured by the special electronic sensors included into the raw information collection system of the computer control center (управляючого комплексу). Their physical and technical specifications, reliability, efficiency of the implemented measurement methodology determine the system's success as a whole.

Creating efficient adaptive systems for maintaining air quality in rooms with a large number of people requires a clear understanding the such objects specifics, considering the number and behavior peculiarities of their present "active" participating constituents, as well as the objective processes taking place in them. It is also necessary to realize the fact that there was no possibility to use universal methods and means of solving the problem due to a large number and individuality of projects and their existing options specificity; due to the limited access to necessary information on their design and technical specifications and opportunities due to commercialization; different level of engineering support and possibilities of a project developers' and real consumers, etc. The available information and certain own developments in this field, trends in the advanced electronic means implementation (with short exposure time, increased accuracy, reliability) and control systems have permitted the authors to continue research on this difficult but extremely relevant subject.

\section{Problem statement}

The research problem was to find out the behavior of constituent components' individual segments in the system of the gas exchange participants: $\mathrm{CO}_{2}$ emissionabsorption processes of different nature and mechanisms in real conditions and in the conditions that imitate different states and actual stay stages of the latter in the academic classrooms during the academic period at fixed values of indicators, uniquely the environment state and the building itself (on the example of a particular an educational institution classroom). The obtained results form the basis of setting tasks and making innovative decisions in designing adaptive complexes for maintaining the building's microclimate quality according to modern technologies.

According to the developed step-by-step methodology it is necessary to:
Calculation of the inflow air flow

$$
\mathrm{V}_{\mathrm{o}}=\mathrm{k} /\left(\mathrm{C}_{\mathrm{s}}-\mathrm{C}_{\mathrm{o}}\right)
$$

where:

$\mathrm{V}_{\mathrm{o}}$ - the volume of inflow air per unit per person, $\mathrm{V}_{\mathrm{e}}$ - breathing rate,

$\mathrm{k}$ - the $\mathrm{CO}_{2}$ amount emitted by a person per time unit,

$\mathrm{C}_{\mathrm{e}}$ - the $\mathrm{CO}_{2}$ concentration in the exhaled air,

$\mathrm{C}_{\mathrm{s}}$ - the indoor $\mathrm{CO}_{2}$ concentration,

$\mathrm{C}_{\mathrm{o}}$ - the $\mathrm{CO}_{2}$ concentration in the incoming air.
- make a real, objective view of the $\mathrm{CO}_{2}$ mass change in the classroom in the course of educational process; - identify the internal $\mathrm{CO}_{2}$ sources and objects of $\mathrm{CO}_{2}$ emission and absorption, and to evaluate their nature; - build a model research system adequate to real processes. To develop a methodology for studying its constituent components;

- take the empirical findings obtained as a basis for the requirements in formulating the tasks for designing and making innovative decisions at appropriate stages during the modern systems designing for maintaining the microclimate quality in the classrooms.

\section{Main material}

Research methods and tools

In order to solve the problem under consideration and to develop an adequate model, a comprehensive sequential methodology was suggested to study the mutual behavior of constituent components present in the indoor air system; the study of their mutual influence degree and activity in varying the staying conditions; the active objects actions on the behavior and changes of the closed system as a whole under the conditions that imitate the real transformations. Each of these fields has both its own academic and applied value.

The study object is the school classroom's air which should be regarded as a complicated interconnected set of interacting environment and the studied room air subsystems, between which (to the extent of its openness and isolation, in this case, heat-mass transfer is performed mainly due to natural or supply-and-exhaust ventilation) the mean value of the air composition indoor $\mathrm{CO}_{2}$ content is determined.

The objects of the present study are the $\mathrm{CO}_{2}$ inflowabsorption processes in the closed classroom air and their influence on the students' physical condition; search for methods to reduce the increased $\mathrm{CO}_{2}$ concentration.

Field indoor air studies on the $\mathrm{CO}_{2}$ content during the education process were carried out directly in the classroom. For the study an ordinary school was selected in a historic building in the center of Poltava, surrounded by commercial and residential buildings, located in the street with lively traffic and a parking place opposite. The classroom was located in the $1 \mathrm{st}$ floor $\left(\mathrm{S}=86,4 \mathrm{~m}^{2}\right.$, $\left.\mathrm{V}=259,2 \mathrm{~m}^{3}\right)$, and had 3 plastic double-chamber windows $\left(6,33 \mathrm{~m}^{2}\right)$. doors $\left(2,84 \mathrm{~m}^{2}\right)$, exterior brick walls $\left(0,8 \mathrm{~m}\right.$ thick, $\mathrm{S}_{\text {outside }}=50,78 \mathrm{~m}^{2}$, waterproof outside; 
grounded and painted inside), 3 heating appliances (thermal energy supplied from other sources (available computers, lightning systems) can be neglected), 3 convection ventilation ducts.

Air exchange modes, which ensure the required classroom air quality and are created by the ventilation system, were worked out in a specially designed flow chamber $\mathrm{V}=9 \mathrm{~m}^{3}$, equipped with a supply and exhaust system (gate valve; ducts, Vents $\varnothing 125 \mathrm{~mm}$; Domovent $125 C T$ fan), air flow rate controller Vents $R S-2 \mathrm{~N}, A M-$ ANEMOMETER 4204 anemometer, a system for dosing and measuring $\mathrm{CO}_{2}$ concentration.

Step by step constituent subprocesses empirical study was carried out by static method in the developed sealed chamber-container (Fig. 2), the equipped with a dismantable hinged holder for sample of studied objects, an internal evaporator dispenser and an external reactor for small and burst $\mathrm{CO}_{2}$ dose-injections by means of a compressor, fan-mixer for internal gas environment, additional internal heater, electronic $\mathrm{CO}_{2}$ meter, hinged studied "passive" absorber plates and photo catalytically active plates-samples, a lighting system.

The study of the processes under study included a sample tests series under appropriate simulation conditions, each beginning with the laboratory chamber ventilation and the equilibrium conditions restoration.

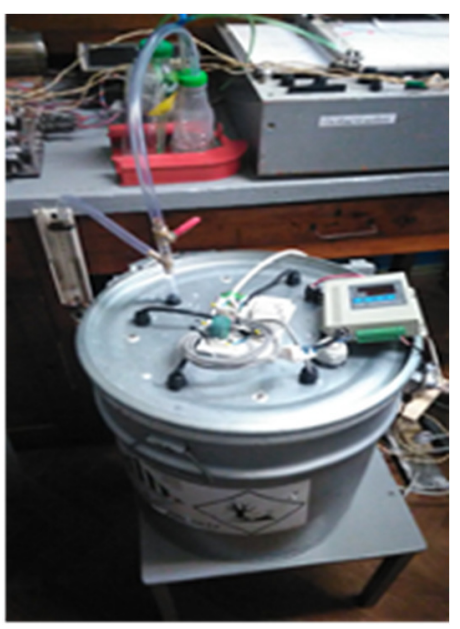

a)

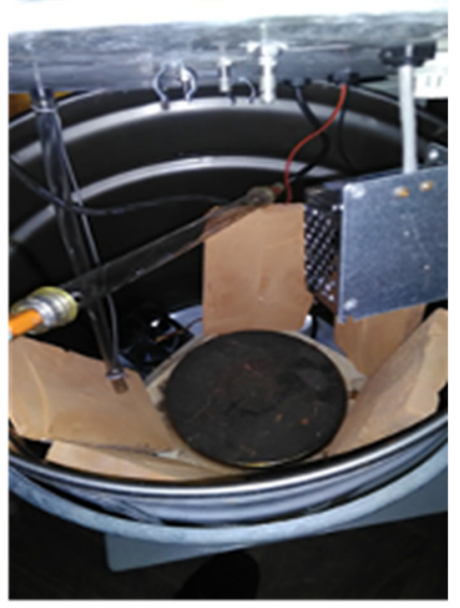

b)

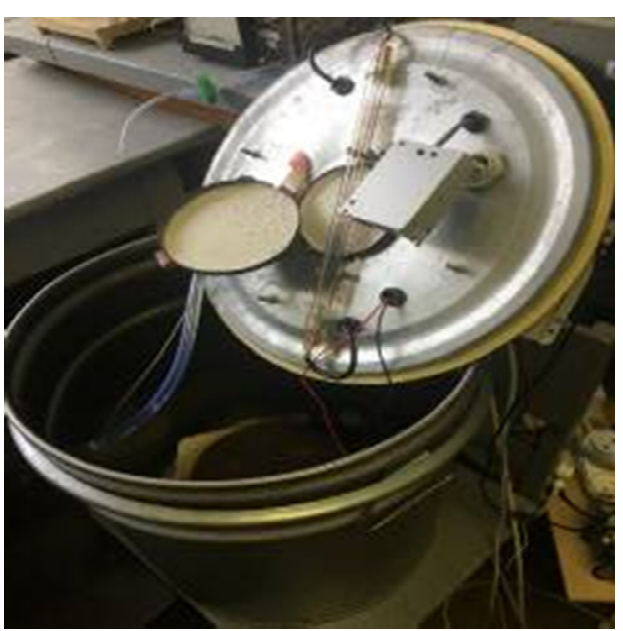

c)

Figure 2 - Chamber for model study of system constituent components participation in the studied processes:

a) external view; b) to understand the adsorbent materials behavior under static conditions; c) for the photos catalytically active components study

The applied static experiment methodology has significant advantage: the sampling and measurements significantly reduces the human impact on the measurement process, which increases the results reproducibility and reduces the measurement errors. It enables more objective assessment of the certain processes effects and factors, influencing the gases generation and emission in the activity zones, as well as assessment of flows from small objects.

The materials selection and development of laboratory units design was performed considering requirements to minimizing their impact on the studied transformations course.

To measure $\mathrm{CO}_{2}$ concentration in the studied environment, $A Z 7755$ (AZ Instrument Corp., Taiwan) portable multifunctional electronic gas analyzer was used, which enables simultaneous measurement of temperature, relative humidity and can be attached to an external interface.

The one-probe system for fixing $\mathrm{CO}_{2}$ concentration enables to measure the averaged total, contribution simultaneously by all the present active emission agents of this gas in the room. In order to clarify the contribution action of individual components, it is necessary to maximally limit the environment influence on the internal heat and mass transformations (by sealing and thermal insulation of the laboratory chamber), more careful consideration of internal sub-processes, existing phenomena (to better understand their mechanisms); introducing simplifications into the proposed thermodynamic model (based on analogies to real study objects); planning the experiment and considering the dominant influence factors with fixing invariability and adequacy of their relevant course conditions; sequential staged study of the causal dependencies.

In the biological experiment with involvement of plants, the following indoor plants were used belonging to Chlorophytum comosum species of the same age and close development stage; with the similar growth conditions (humus quality, humidity, temperature); with a known vegetative leaf cover area; planted in pots with a sealed bottom.

The following illuminators were used: a fluorescent low pressure ionizing radiation lamp (simulating daylight) with $8 \mathrm{~W}$ of power and a bactericidal lamp with same power with the wavelength $\sim 254 \mathrm{~nm}$. The illumination nature was changed by the use of the appropriate illuminator type (spectral composition), the intensity was altered by the number of sources used, the distance to the samples, the shape and area of the latter. 
Plates, made of aluminosilicate clays by a technology similar to the ordinary building bricks manufacturing were used as adsorbents.

The required calculated $\mathrm{CO}_{2}$ volume used to simulate the external conditions, was created by a chemical equivalent interaction in aqueous sodium bicarbonate and hydrochloric acid solutions, taken in the appropriate amounts.

\section{Results of the study and their discussion}

The work was aimed at characterizing the system under study, development of methodology for study and subprocesses consideration stages with determining the degree of dominance factors influence on the object under study.

Stage I. Air study in school classroom.

The air microclimate study in the classroom was carried out in October 2019. The averaged data obtained during the school day, in a classroom with 32 pupils with an mean air volume of $8,1 \mathrm{~m}^{3} /$ person, in the fixed conditions in two stay modes (see Fig. 3, 4) clearly demonstrate the ventilated room's advantages (opening windows during breaks between lessons) in carbon dioxide content.

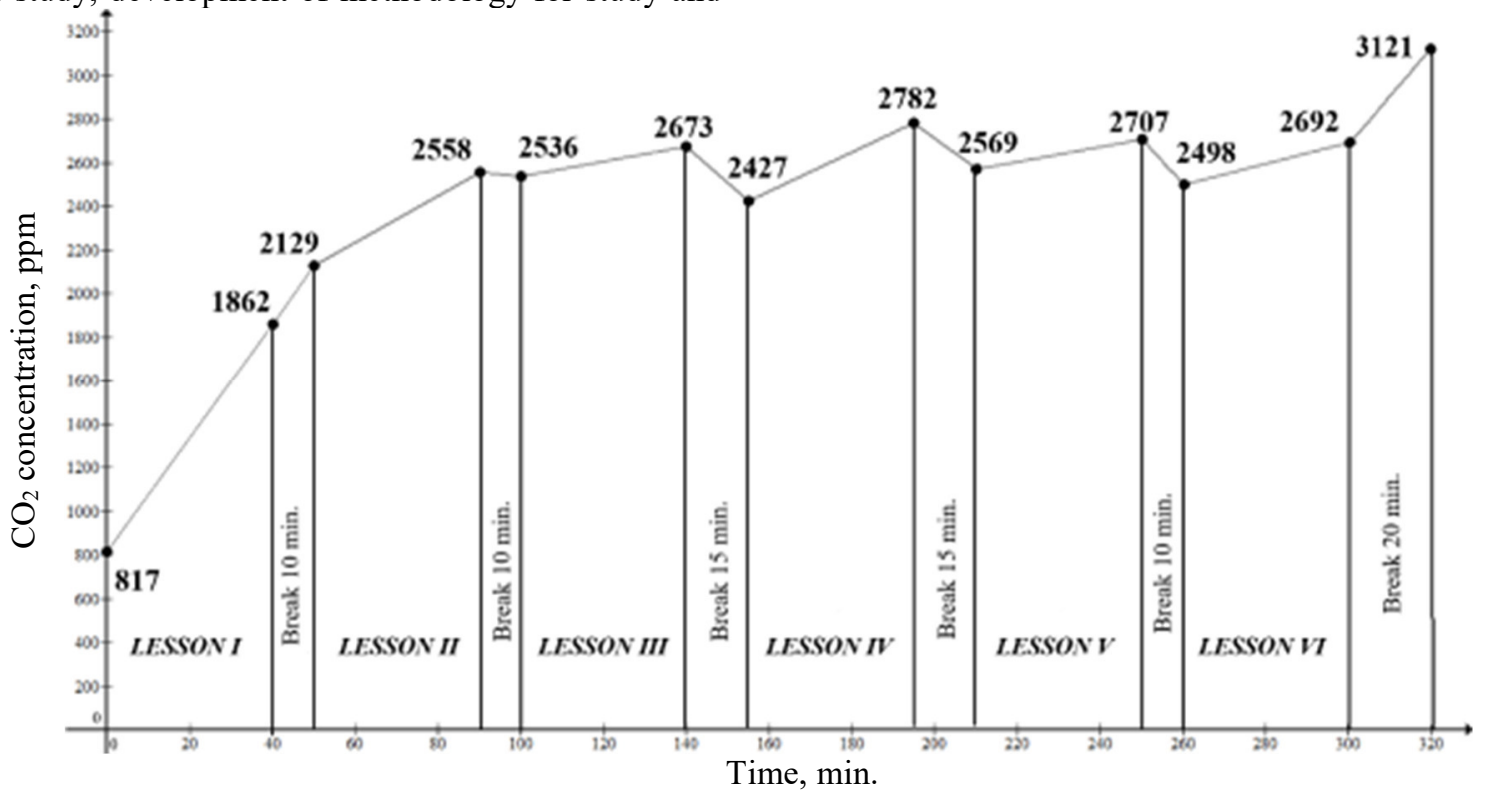

Figure 3 - $\mathrm{CO}_{2}$ concentration change of indoor air with time in stay mode $\mathrm{I}$ (without airing a closed classroom $\mathrm{V}=\mathbf{2 5 9 , 2} \mathrm{m}^{3}$ during breaks between lessons at fixed values of $\mathrm{t}=19,3^{\circ} \mathrm{C} ; \mathrm{CO}_{2}$ concentration $=502 \mathrm{ppm} ; \mathrm{r}=49 \%$ )

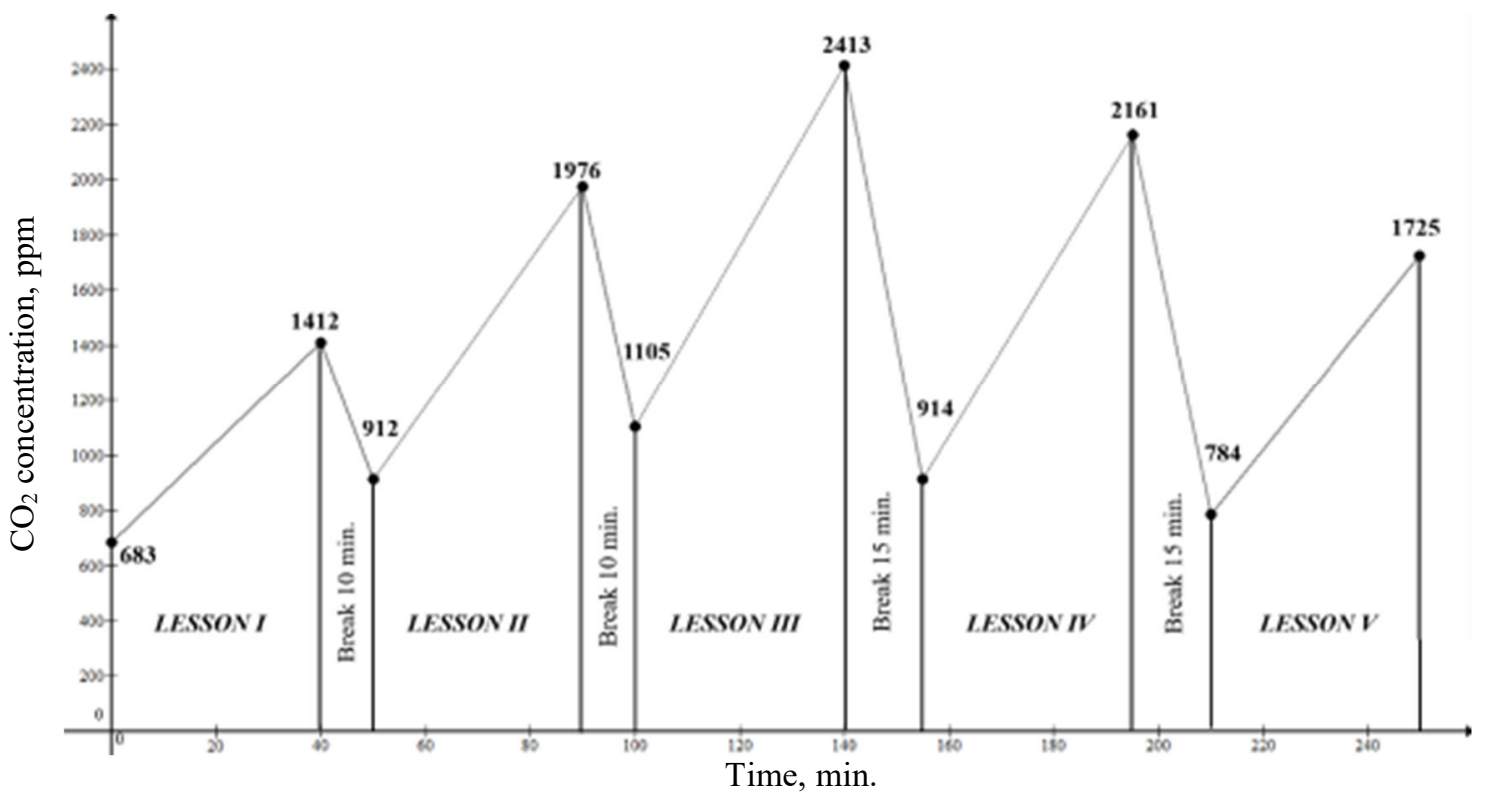

Figures $4-\mathrm{CO}_{2}$ concentration change of indoor air with time in stay mode II (with airing a classroom $\mathrm{V}=\mathbf{2 5 9 , 2} \mathrm{m}^{3}$ during breaks between lessons at fixed values of $\mathrm{t}=19,3^{\circ} \mathrm{C} ; \mathrm{CO}_{2}$ concentration $=502 \mathrm{ppm} ; \mathrm{r}=49 \%$ )

In mode $I$ in an unventilated room during the study such circumstances, the $\mathrm{CO}_{2}$ concentration will be 1900 time, the background ventilation rate is $\mathrm{k}=0,1 \mathrm{~h}^{-1}$. In ppm already at the end of the first lesson (contributes to 
the increase in humidity and temperature) far exceeding the recommended $1000 \mathrm{ppm}$. By the end of all lessons, the concentration will increase by 3 times (3365 ppm) - this value is significantly unfavorable for the efficient pupils' work in the classroom.

When ventilating in mode II (during each break, windows and doors open, all pupils leave the classroom) the air environment condition in the classroom improves compared to the previous version. However, the $\mathrm{CO}_{2}$ concentration remains high at the end of the classes, it significantly exceeds the recommended values. This method of stabilizing $\mathrm{CO}_{2}$ concentration becomes unfavorable in terms of heat losses, especially in winter (when $\mathrm{t}_{\text {outside }}$ is $\sim-18^{\circ} \mathrm{C}$ ), it can cause diseases of the modern people.

The performed field study really clarifies the dynamics and changes range in the $\mathrm{CO}_{2}$ concentration during the studied processes, enables modeling the latter, predicting the ways to optimize solutions when constructing engineering support systems for providing quality microclimate in classrooms.

Stage II.. Indoor air quality and ventilation

This stage was aimed to determine optimal ventilation system's efficient operation mode with different ways of organizing air exchange indoors, the air quality indicator being the $\mathrm{CO}_{2}$ content.

When designing ventilation systems and calculating heat loads, the required air exchange is specified in the design documentation in compliance with the requirements and regulatory documents recommendations [10, 11]. When designing and operating, isolate or eliminate or at least reduce emissions of the major harmful sources. Additional air purification systems are also used to improve the indoor air quality.

At minimum, the ventilation air exchange must be sufficient to disperse the biological human`s discharge. In addition, the air exchange increases by the discharge amount from the building itself and its engineering systems. According to table 3 [11], the recommended total specific values (in terms of one person) of ventilation air exchange for classrooms (category I premises with very small discharge) is $19,8 \mathrm{~m}^{3} / \mathrm{h}$. The air exchange rate was found to be $2,5 \mathrm{~h}^{-1}$, the air flow rate was $\sim 0,45$ $\mathrm{m} / \mathrm{s}$.

During the experiments to ensure the estimated inlet air flow in the various implemented modes (see graphs in Fig. 5), carried out by regulating and controlling the air flow rate and with the parallel addition of appropriate $\mathrm{CO}_{2}$ doses, simulating gas discharges during the educational process, and measuring its concentration changes within the set time to stabilize the $\mathrm{CO}_{2}$ concentration (thus, at $\mathrm{k}=2,5 \mathrm{~h}^{-1}-$ after $\sim 23 \mathrm{~min}$.). Dependencies are asymptotic. Thus, the proper sanitary and hygienic conditions in the studied classrooms are ensured.

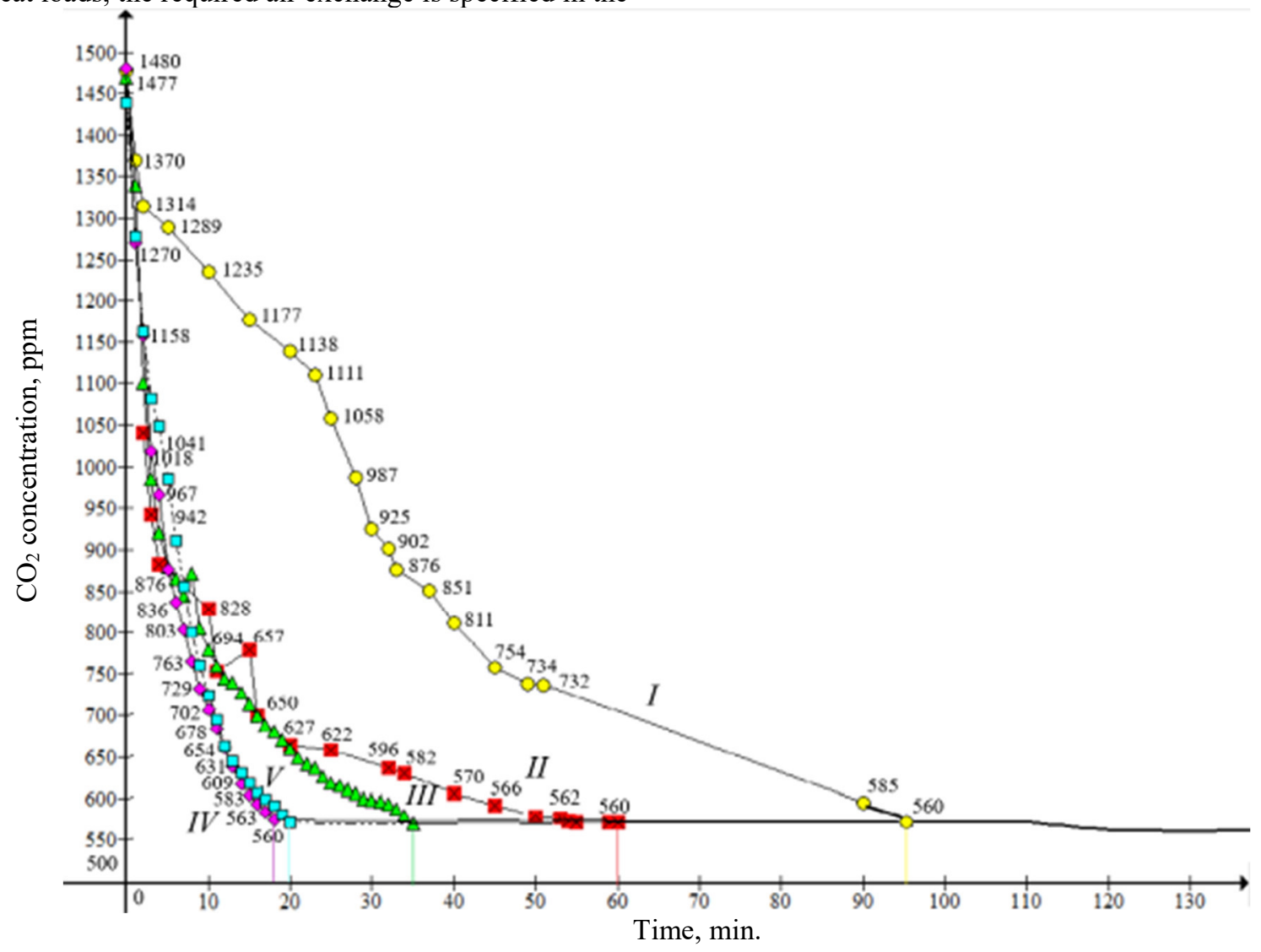

Figure 5 - The nature of $\mathrm{CO}_{2}$ concentration changes in the laboratory chamber over time during the tests in different modes of air exchange and burst injection of same initial carbon dioxide doses I - k= 1,00 h. ${ }^{-1}$; II - k= 1,50 h..$^{-1}$; III - k= 2,00 h..$^{-1}$ IV - k= 2,75 h. ${ }^{-1}$ V - k= 3,65 h.-

Stage III. $\mathrm{CO}_{2}$ contribution by the modern plants in the closed classroom air

The study was carried out in a specially designed sealed chamber (Fig. 6) in order to clarify the intensity 
effect and spectral radiation composition on the plants photosynthetic activity (through the example of Chlorophytum comosum), in the conditions close to real ones. The plants behavior when illuminated (dimmed) by a fluorescent "daylight" lamp is clearly characterized by the empirical data in Figs. 7-8, Tables 1, 2, by the experiment conditions, by the calculated mean conditional specific trends (indices).

To obtain correct study results in the specified regimes at different imitating initial $\mathrm{CO}_{2}$ doses (see Tables 1-2) the study was performed with the same plant; at constant temperature; while minimizing losses due to leakage and the absence of other potential object- participants. In the both experiments, the lower plant part was gas-insulated; the total active leaves surface area was $\sim 3200 \mathrm{~cm}^{2}$.

In Fig. 7 the highlighted color zone reflects the evolutionary changes nature in the $\mathrm{CO}_{2}$ content in room air over time in the fixed range concentrations from its highest to the lowest values; the upper limit determines the time zone for the $\mathrm{CO}_{2}$ content index values recovery in the classroom to its initial level in the first scenario, i. e. without ventilation (Fig. 1) with the flow up to $4000 \mathrm{ppm}$; the lower limit - in the second scenario (with ventilation) and the flow up to $1500 \mathrm{ppm}$.

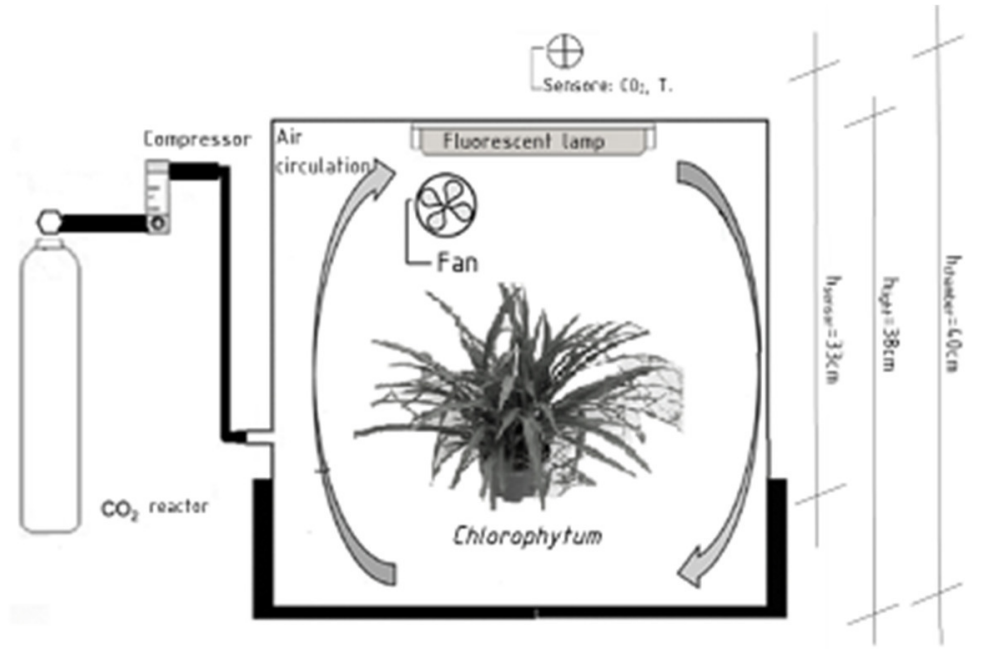

Figure 6 - Laboratory chamber for studying the plants activity in simulated conditions

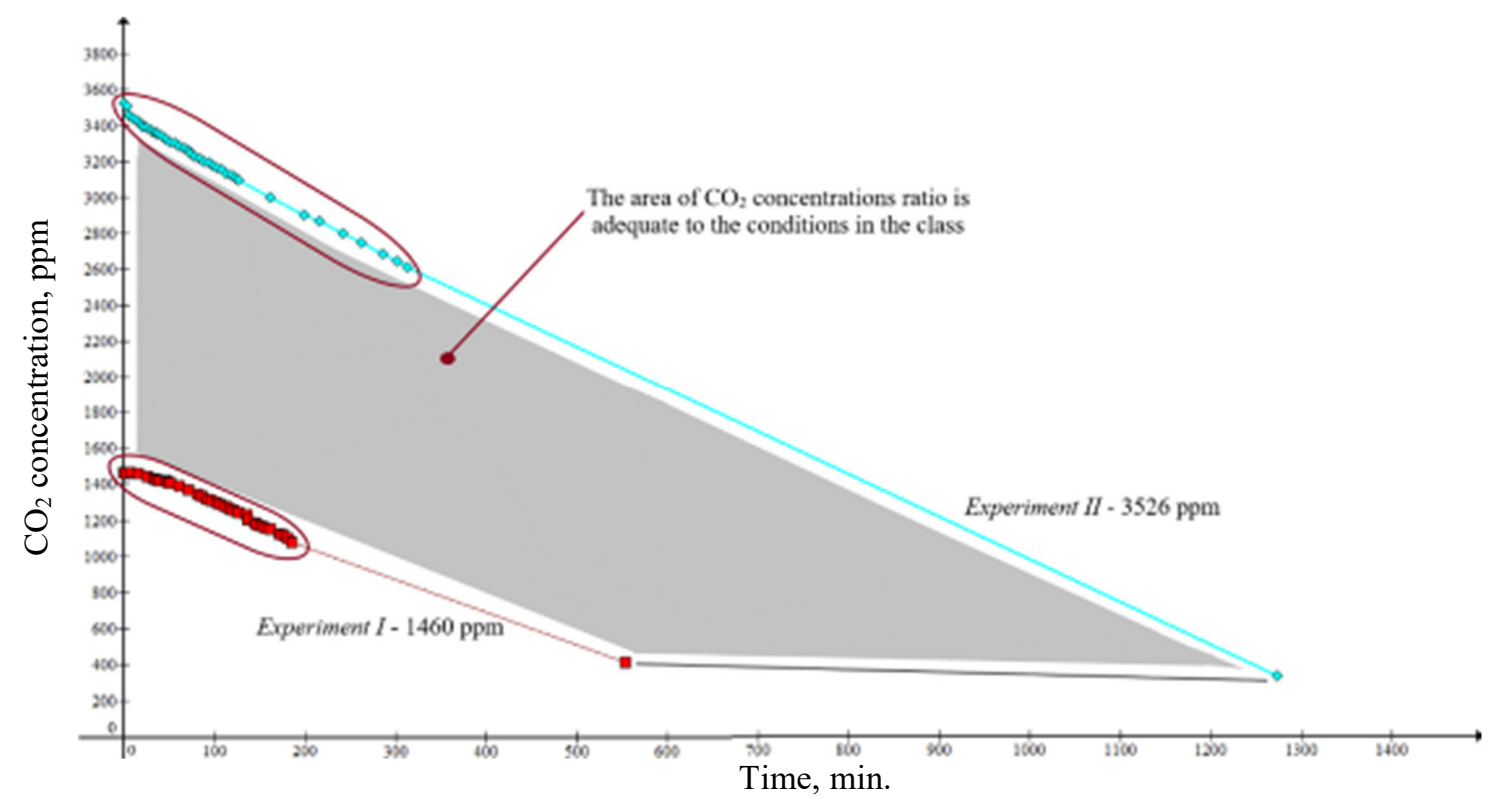

Figure 7 - Injected $\mathrm{CO}_{2}$ burst dose influence on the restorative processes duration in the studied air volume of the plant in photosynthesis mode (under static conditions) 


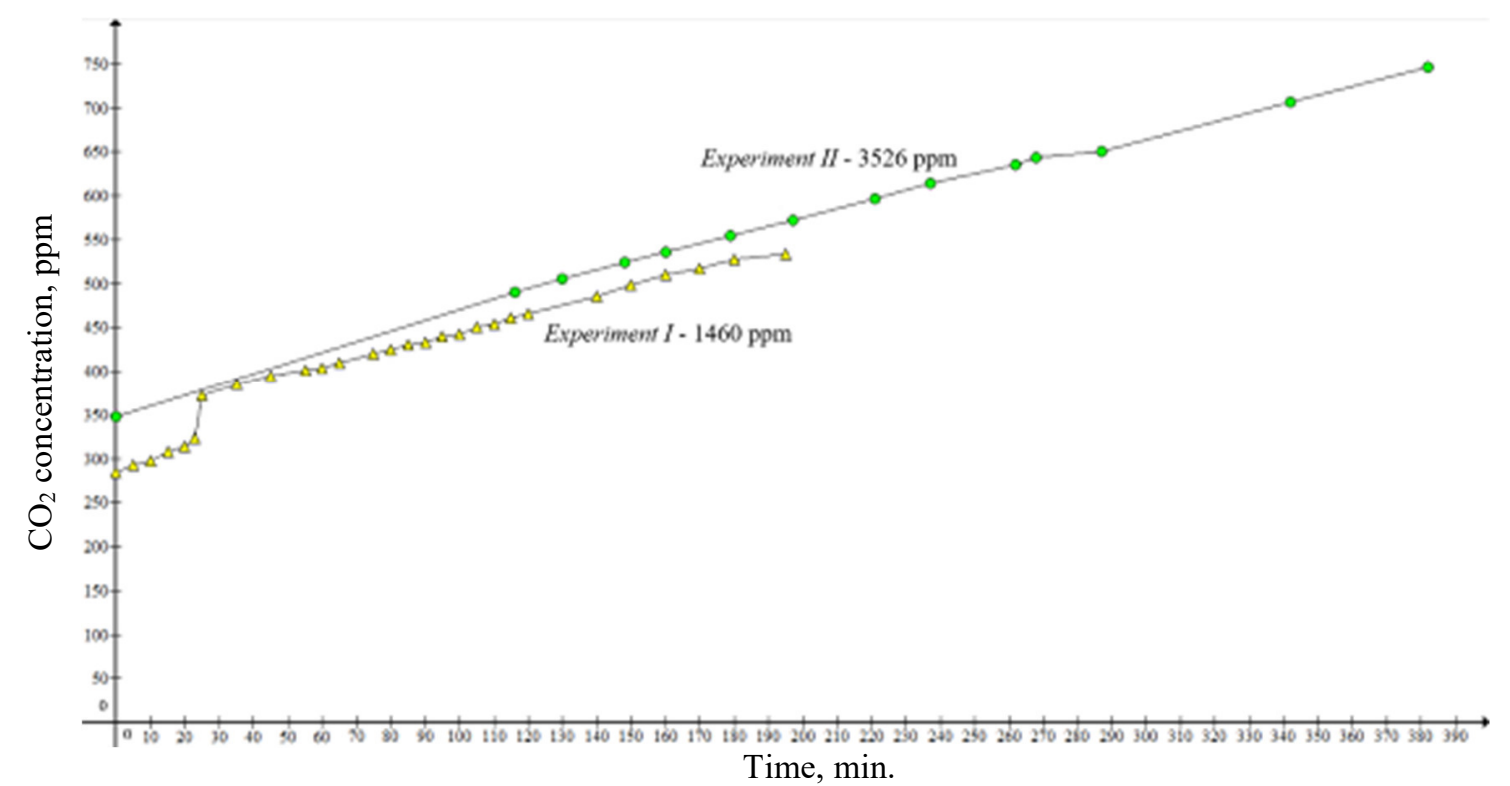

Figure $8-\mathrm{CO}_{2}$ emission by the plant in the "darkening" stage for a long time after the photosynthesis period in experiments I, II (without changing other conditions)

Table 1 - The plant activity during daytime - artificial light

\begin{tabular}{|l|l|}
\hline \multicolumn{1}{|c|}{ Experiment $I$} & \multicolumn{1}{c|}{ Experiment II } \\
\hline \multicolumn{2}{|c|}{$\mathrm{t}=19^{\circ} \mathrm{C}$} \\
\hline \multicolumn{2}{|c|}{$\mathrm{S}_{\Sigma \text { act. }}=3200 \mathrm{~cm}^{2}$} \\
\hline $\begin{array}{l}\text { Initial concentration } \\
\mathrm{CO}_{2}=1460 \mathrm{ppm}\end{array}$ & $\begin{array}{l}\text { Initial concentration } \\
\mathrm{CO}_{2}=3526 \mathrm{ppm}\end{array}$ \\
\hline$\tau_{\Sigma}=185 \mathrm{~min}$. & $\tau_{\Sigma}=313 \mathrm{~min}$. \\
\hline$\Delta \mathrm{CO}_{2}=395 \mathrm{ppm}$ & $\Delta \mathrm{CO}_{2}=911 \mathrm{ppm}$ \\
\hline $\mathrm{V}_{\text {aver. }}=3,29 \mathrm{ppm} / \mathrm{min}$. & $\mathrm{v}_{\text {aver. }}=2,91 \mathrm{ppm} / \mathrm{min}$. \\
\hline $\begin{array}{l}\mathrm{V}_{\text {aver. active. }}=1,02 \cdot 10^{-3} \\
\mathrm{ppm} / \mathrm{cm}^{2} \cdot \mathrm{min} .\end{array}$ & $\begin{array}{l}\mathrm{V}_{\text {aver. active. }}=0,91 \cdot 10^{-3} \\
\mathrm{ppm} / \mathrm{cm}^{2} \cdot \mathrm{min} .\end{array}$ \\
\hline
\end{tabular}

Oval highlighted segments characterize the $\mathrm{CO}_{2}$ amounts used by a plant during its photosynthetic activity (reducing the $\mathrm{CO}_{2}$ content in room air) over a working day ( $\sim 5-6$ hours) under the conditions imitating the largest and the smallest $\mathrm{CO}_{2}$ discharge from the modern people.

The nature of such $\mathrm{CO}_{2}$ use by the plant approaches to that proportional with time (this is indicated by the tangent slope angle of arrival to empirical concentration dependences on time). In close premises, $\mathrm{CO}_{2}$ concentration (under other conditions unchanged) may be less than its content in the supply air. It enables implementation of conditional specific trends, characterizing the biological plant species behavior, (indices) (see Tables 1,2 ), by which, to some extent, their activity in the studied processes can be roughly assessed under the appropriate conditions. It enables to approximately determine the required time interval to restore the level of $\mathrm{CO}_{2}$ content to its initial values and the required amount of the above species plants. In experiments I, II with carbon dioxide concentration
Table 2 - The plant activity in the "eclipse" stage

\begin{tabular}{|c|c|}
\hline Experiment I & Experiment II \\
\hline \multicolumn{2}{|c|}{$\mathrm{t}=19^{\circ} \mathrm{C}$} \\
\hline \multicolumn{2}{|c|}{$\mathrm{S}_{\Sigma \text { act. }}=3200 \mathrm{~cm}^{2}$} \\
\hline $\begin{array}{l}\text { Initial concentration } \\
\mathrm{CO}_{2}=1460 \mathrm{ppm}\end{array}$ & $\begin{array}{l}\text { Initial concentration } \\
\mathrm{CO}_{2}=3526 \mathrm{ppm}\end{array}$ \\
\hline$\tau_{\Sigma}=194 \mathrm{~min}$ & $\tau_{\Sigma}=382 \mathrm{~min}$ \\
\hline$\Delta \mathrm{CO}_{2}=249 \mathrm{ppm}$ & $\Delta \mathrm{CO}_{2}=399 \mathrm{ppm}$ \\
\hline $\mathrm{v}_{\text {aver. }}=1,28 \mathrm{ppm} / \mathrm{min}$. & $\mathrm{v}_{\text {aver. }}=1,04 \mathrm{ppm} / \mathrm{min}$. \\
\hline $\begin{array}{l}\mathrm{V}_{\text {aver. active. }}=0,40 \cdot 10^{-3} \\
\mathrm{ppm} / \mathrm{cm}^{2} \cdot \mathrm{min} .\end{array}$ & $\begin{array}{l}\mathrm{V}_{\text {aver. active. }}=0,33 \cdot 10^{-3} \\
\mathrm{ppm} / \mathrm{cm}^{2} \cdot \mathrm{min} .\end{array}$ \\
\hline
\end{tabular}

up to $4000 \mathrm{ppm}$, the conditional specific index and photosynthetic plant activity of the Chlorophytum comosum species plants are hardly changed.

When switching off the lighting (during dimming, under the same adequate conditions, with presence of the same plant), reverse $\mathrm{CO}_{2}$ emission process occurs (see Fig. 8), but much slower (in this case, by $2,5 \div 3$ times) compared to the activity at the photosynthetic stage. In experiments I and II (with different additionally introduced carbon dioxide doses into the working volume) it is found that from the moment of reaching the initial $\mathrm{CO}_{2}$ concentration level the course of concentration dependences passes through close intermediate states, which testifies to similar mechanism of their transformations, their repeatability, reproducibility, and, therefore, some plant behavior stability over time under certain conditions and with close mean conditional index values of its activity.

The obtained data acquire value when using the similar biological properties forms in applied innovative solutions. 
Previous studies [19-21] found that Chlorophytum comosum exhibits the highest photosynthetic activity at irradiation with wavelengths in areas with maxima of 440-445 $\mathrm{nm}$ (in the blue spectrum part required for vegetative development) and at $640-660 \mathrm{~nm}$ (in the red zone, that is necessary for all adult plants for reproductive development and for strengthening the root system).

Significant absorption spectral activity for the studied plant in the electromagnetic waves range, which is emitted by fluorescent daylight lamps, was established and characterized in the results of the above studies. Hard radiation $(254 \mathrm{~nm}$, of the same power $-8 \mathrm{~W})$ of the bactericidal lamp revealed irreversible destructive effect on plant living cells, that was established due to the sharp increase of $\mathrm{CO}_{2}$ concentration in the operation zone air after several hours of exposure.

The influencing factors on the $\mathrm{CO}_{2}$ contribution by the modern plants in the air of the closed classroom were:

- plants species,

- their number,

- their development stage and their condition,

- lighting system (its intensity, spectrum) applied,

- carbon dioxide content in the surrounding atmosphere,

- favorable plants conditions (humidity, soil quality, environmental temperature, pot and root system openness, etc.),

- features of photometric factors influence,

- the active photosynthesizing surface area size and its condition,

- the ratio of contributions due to activity at the "photosynthesis" and "darkening" stages.

The original obtained data need detailed consideration and further study using more sophisticated methods and precision technical experimentation equipment.

Stage IV. Influence of artificial mineral aluminosilicate adsorbing materials present on the composition of room air mass.

This effect manifestation and its activity are due to the physical heterogeneous adsorption on the interphase surfaces: the room air - building elements porous surfaces.

According to modern concepts, physical adsorption is caused by dispersion, orientation and deformation interaction forces. The gas medium molecule energy interaction with the solid adsorbent surface, caused by intermolecular forces, decreases proportionally $\sim 1 / r^{3}$ ( $r$ is the distance from the molecule center to the phase disengagement boundary). At $r=3 r_{\mathrm{o}}$ ( $r_{\mathrm{o}}$ is the radius of the molecule) the adsorption potential decreases up to $3 \div 4 \%$ of its value near the surface. This leads to the conclusion that the gas is adsorbed in the monomolecular layer form on the energetically inhomogeneous adsorbent surface. The molecule transition from one site to another may be related to overcoming some energy barrier (localized adsorption). In such a heterogeneous process, mass transfer processes play an essential role; adsorption and diffusion transfer itself; the phase disengagement surface area, its nature and condition.
There are currently no sufficiently reliable methods to determine or calculate the particles activity, that are located at the phases disengagement boundary Therefore, in determining the adsorbent behavior activity or the products concentration in substrate molecules interaction with potential participants, it is necessary to introduce conditional concepts - conditional transformation rate (trend) index, attributed to the interphase surface unit with introduction of the appropriate assumptions and time intervals.

The particular surface atoms or molecules energy state, their geometric arrangement determines the specific kinetic regularities of these heterogeneous transformations. For the most part, they are multi-staged. And the heterogeneous process speed as a whole depends on the individual stages speed and their ratio.

Adsorption transformations are reversible. Their equilibrium constants depend on pressure, temperature. At a given temperature, the pressure increase promotes desorption, its decrease - adsorption; at a given pressure, increasing of the temperature promotes desorption, decreasing - adsorption. These features of adsorbing materials behavior are the basis of the modern cyclic purification systems work with regeneration. They are $\mathrm{CO}_{2}$ redistribution objects in a separate room, this study is dedicated to their behavior. Such phenomena do not require significant energy activation and last for a very short time.

Any really existing object is in complex interrelationship with the environment and exhibits a complicated behavior in natural gas exchange processes, in which the absorption-release processes are only constituents. To simulate such active samples behavior, with a characteristic dominant adsorption-desorption property, an experiment was performed using porous aluminosilicate adsorption plates under the conditions simulating a change in the $\mathrm{CO}_{2}$ concentration in the air room volume, cyclic daily and seasonal changes in temperature; the stay conditions peculiarities and environment composition, the specific individual factors effect, etc. (see Fig. 9-10).

Table 3 -- Assessment of the constituent components conditional activity in the $\mathrm{CO}_{2}$ content reduction processes in the studied air zones, related to plant photosynthesis and adsorption by artificial aluminosilicate materials

\begin{tabular}{|l|l|}
\hline Photosynthesis & Adsorption \\
\hline $\mathrm{S}=3200 \mathrm{~cm}^{2}$ & $\mathrm{~S}=1075 \mathrm{~cm}^{2}$ \\
\hline $\mathrm{t}=18,8^{\circ} \mathrm{C}$ & $\mathrm{t}=19,0^{\circ} \mathrm{C}$ \\
\hline$\tau_{\Sigma}=313 \mathrm{~min}$. & $\tau_{\Sigma}=301 \mathrm{~min}$. \\
\hline$\Delta \mathrm{CO}_{2}=911 \mathrm{ppm}$ & $\Delta \mathrm{CO}_{2}=1588 \mathrm{ppm}$ \\
\hline $\mathrm{v}_{\text {сер. }}=2,91 \mathrm{ppm} / \mathrm{min}$. & $\mathrm{V}_{\text {сер. }}=5,28 \mathrm{ppm} / \mathrm{min}$. \\
\hline $\begin{array}{l}\mathrm{v}_{\text {сер. акт. }}=0,91 \cdot 10^{-3} \\
\text { ppm } / \mathrm{cm}^{2} \cdot \mathrm{min} .\end{array}$ & $\begin{array}{l}\mathrm{V}_{\text {сер. акт. }}=4,91 \cdot 10^{-3} \\
\text { ppm } / \mathrm{cm}^{2} \cdot \mathrm{min} .\end{array}$ \\
\hline
\end{tabular}




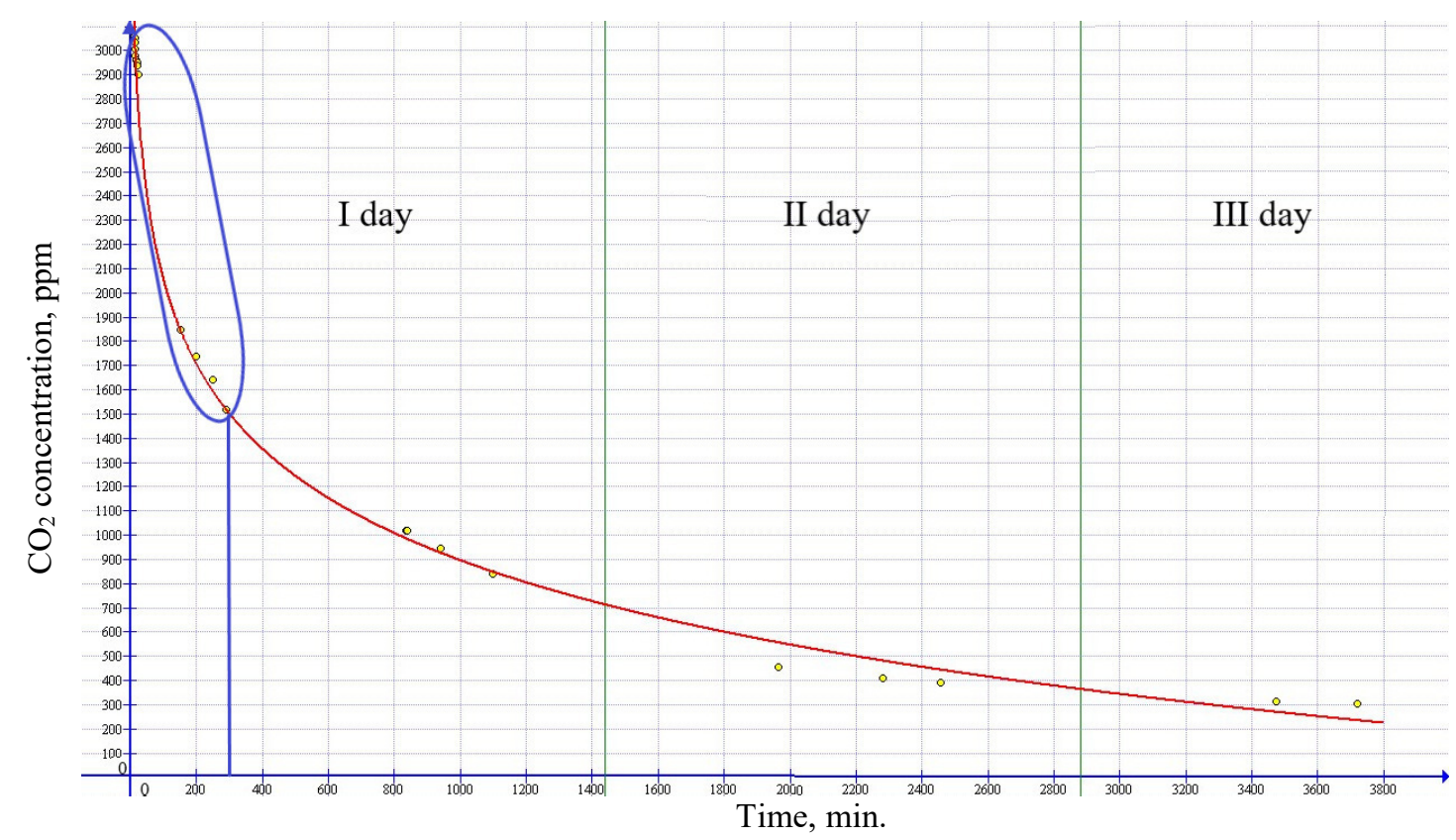

Figure 9 - Change of $\mathrm{CO}_{2}$ concentration in the closed chamber with time in the artificial aluminosilicate plates $\left(S=1075 \mathrm{~cm}^{2}, T=292 \mathrm{C}\right.$, burst $\mathrm{CO}_{2}$ introduction $\sim 3100 \mathrm{ppm}$; chamber volume $-40 \mathrm{dm}^{3}$, static method; under conditions imitating stay length in the classroom during weekdays; during weekends)

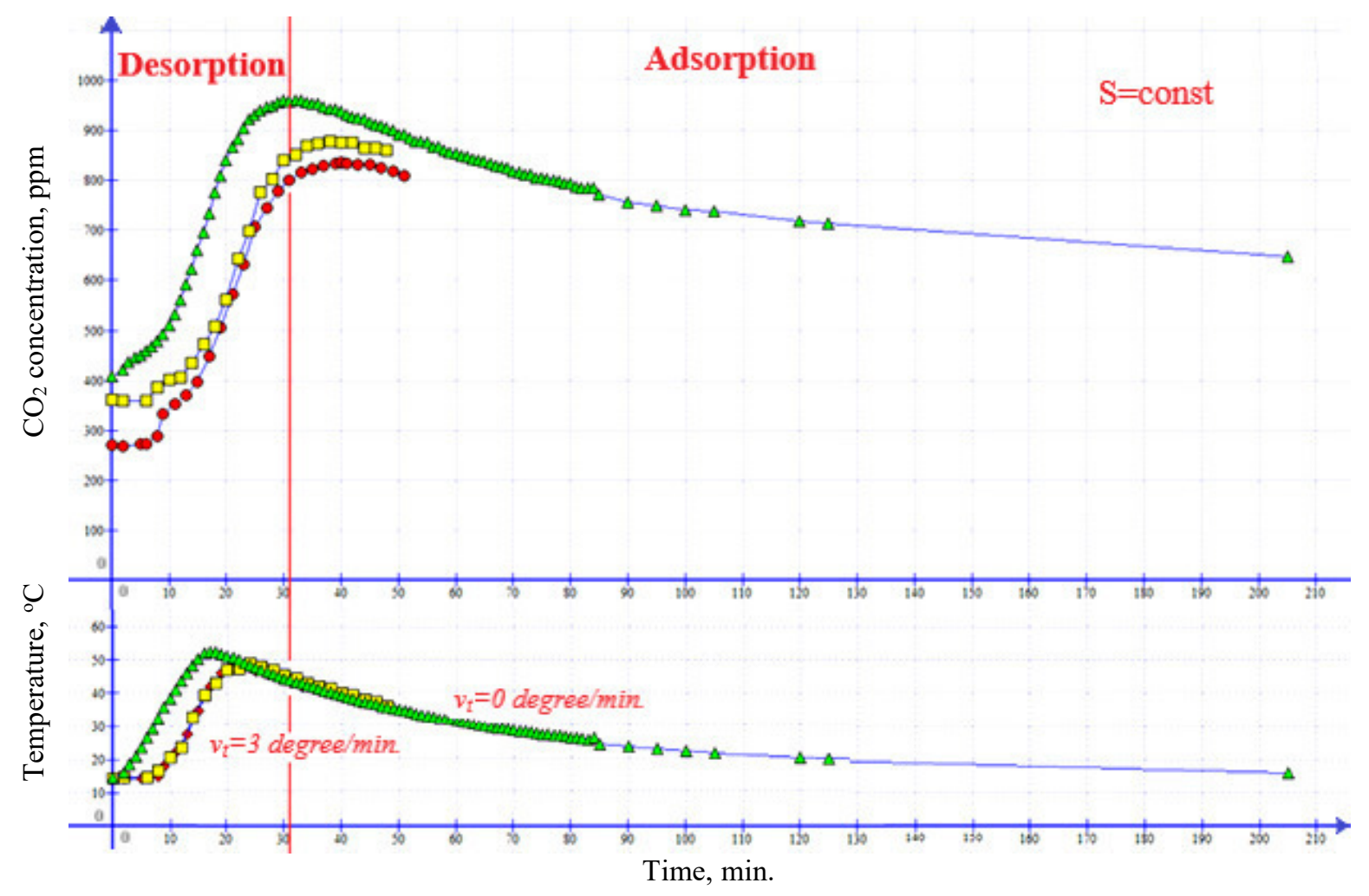

Figure 10 - Modeling behavior and analysis of properties reproducibility and artificial aluminosilicate adsorbing materials physical and technical characteristics in 3 cyclic tests series:

heating (at a rate of 3 degree/min.) - cooling in a closed space and constant $S_{\text {adsorption }}$ 
Modeling of processes with adsorption-active objects was carried out:

a) with an internal $\mathrm{CO}_{2}$ source,

b) with an external source (for example, simulating $\mathrm{CO}_{2}$ concentration in inlet air):

- low intensity,

- high intensity.

In the simulation, the gas "burst" effect value on the system under study was chosen commensurate with $\Delta \mathrm{CO}_{2}$ value during the active influence period within the working education shift, during the weekend.

A comparative plant life processes analysis and the re-release by the studied adsorbents using averaged indices system in the formation of $\mathrm{CO}_{2}$ contribution to the study object indicates that the absorbent surfaces action influence in adsorbing construction surfaces products is by $\sim 4,9$ times higher than the biological detectable activity, (considering particular staying conditions, with all these phenomena differences in their nature and behavior features). To change their action efficiency it is necessary to vary: the forms and types of constituent participants, active areas, thermodynamic systems conditions, time and exposure mode, etc.

This will form the further research basis.

Generalized empirical data on adsorption and desorption by adsorbent material in cyclic heating are graphically interpreted in fig. 10.

Alumosilicate porous clay products were selected as the adsorbent, dried and annealed according to the brick manufacture technology. This enables on the one hand

a) to simulate the $\mathrm{CO}_{2}$ absorption processes using constructions made of such material,

b) on the other hand, to purposefully create adsorption channels for the design and construction of objects and providing them with air-purification systems (large classrooms in educational establishments, large concert and sports arenas, training halls, waiting rooms, large shopping centers, etc.),

c) the acquired knowledge permit to better know and understand the phenomena nature, mechanisms, kinetics, activation ways; to improve their efficiency and operational capacities.

The study evaluated the $\mathrm{CO}_{2}$ adsorption-desorption processes contribution to the total heterogeneous set of gas-exchange transformations and determined their significance. The empirical data obtained are valuable for understanding the impact of changing the studied object conditions on the equilibrium processes displacement direction and the related transformations permit generalization.

The empirical study of artificial aluminosilicate adsorbing products adsorption-desorption processes enables:

- to know and understand the phenomena nature, mechanisms, kinetics, activation ways better; improve their efficiency and operational capacities;

- to find out the prevailing tendencies manifestation conditions, which enables to organize appropriate operation modes for purification complexes;

- to understand the facts that

a) in the dynamic heating mode due to the limited heat transfer speed, active $\mathrm{CO}_{2}$ molecules exchange centers in the contact adsorbing material layer are involved in interaction with some delay. That is registered with the $\mathrm{CO}_{2}$ concentration measurement system in the operating test facility volume.

b) transformation cycles repeatability and reproducibility permit to predict operation stability and reliability, principles of designed systems functioning;

c) the hysteresis properties dependencies narrowness enables stable operation of technically implemented systems;

d) low temperature values for reversing the transformations domination indicate the possibility to choose an easy, in energy terms, construction variant of purification (accumulation) systems even with the use of renewable energy sources low-power means;

- to identify directions for searching efficient alternatives to the already existing solutions.

Such an experimental study is complex, needs much labor input and a long time to establish equilibrium conditions. It requires stability in the measurement system's operation, performing tests in adequate conditions.

Stage V. Model ideas about the processes in the particular school classroom air.

The separate classroom air should be considered as a multi-component open subsystem with a strong connection with environment, each present component of which is an active participant in complex by nature (often understudied) multi-staged transformations. Most components properties are environment parameters functions. And when the state of the latter changes, the interactions course becomes reversible, the transformations depth in such objects will depend on the set of specific intense actions and extensive factors.

The $\mathrm{CO}_{2}$ flow into the room air space occurs:

1) from an external source - from environment air space

- through inlet air supply by means of the implemented ventilation system (prevailing) and is determined

a) by the degree of room isolation from the environment,

b) by the degree of air exchange provided by the particular applied ventilation means;

- as a result of mass-gas exchange through enclosing structures, etc.;

2) from internal living and non-living origin sources in the process of

- carbon dioxide emissions generated by people in the occupied space;

- activity manifestation in the modern plants life in the conditions under consideration;

- changes in the behavior of the existing adsorbing surfaces present, etc.;

3 ) when changing the stay conditions

- under changes in intensive and extensive external and internal factors influence,

- under influence of factors that cause changes in the direction and resulting processes magnitude, nature, relation, dominance;

- maintaining the stability and reproduction of the hysteresis physical properties of the used active objects in the course of relaxation transformations; 
- under other factors influence.

The results of systematic versatile multi-staged studies on detecting the $\mathrm{CO}_{2}$ contribution by constituent components to the separate room airspace, permitted to obtain our own and literature data $[22,23]$ on the possibility of implementing activation methods for air purification using new photocatalytically active layered perovskite-like oxide materials $\mathrm{M}_{2} \mathrm{Ln}_{2} \mathrm{Ti}_{3} \mathrm{O}_{10}$ (M - Li, Na, K; Ln - La, Nd) (see Fig. 2 c) are necessary prerequisites for formulating the technical requirements and development for designing the adaptive systems to maintain a microclimate, with the possibility to regulate inlet-recirculation air flows ratio and adsorption and photocatalytic treatment (both solar and artificial radiation) and using composite $\mathrm{TiO}_{2}$-containing materials, their modifications (as an example, see Fig. 11).

The obtained results open the search directions for development of modern systems for separation, purification, regeneration, accumulation, $\mathrm{CO}_{2}$ storage, its partial or complete restoration; improvement of their technical capacities and specifications using innovative solutions and may become a necessary scientific basis for engineering generalizations.

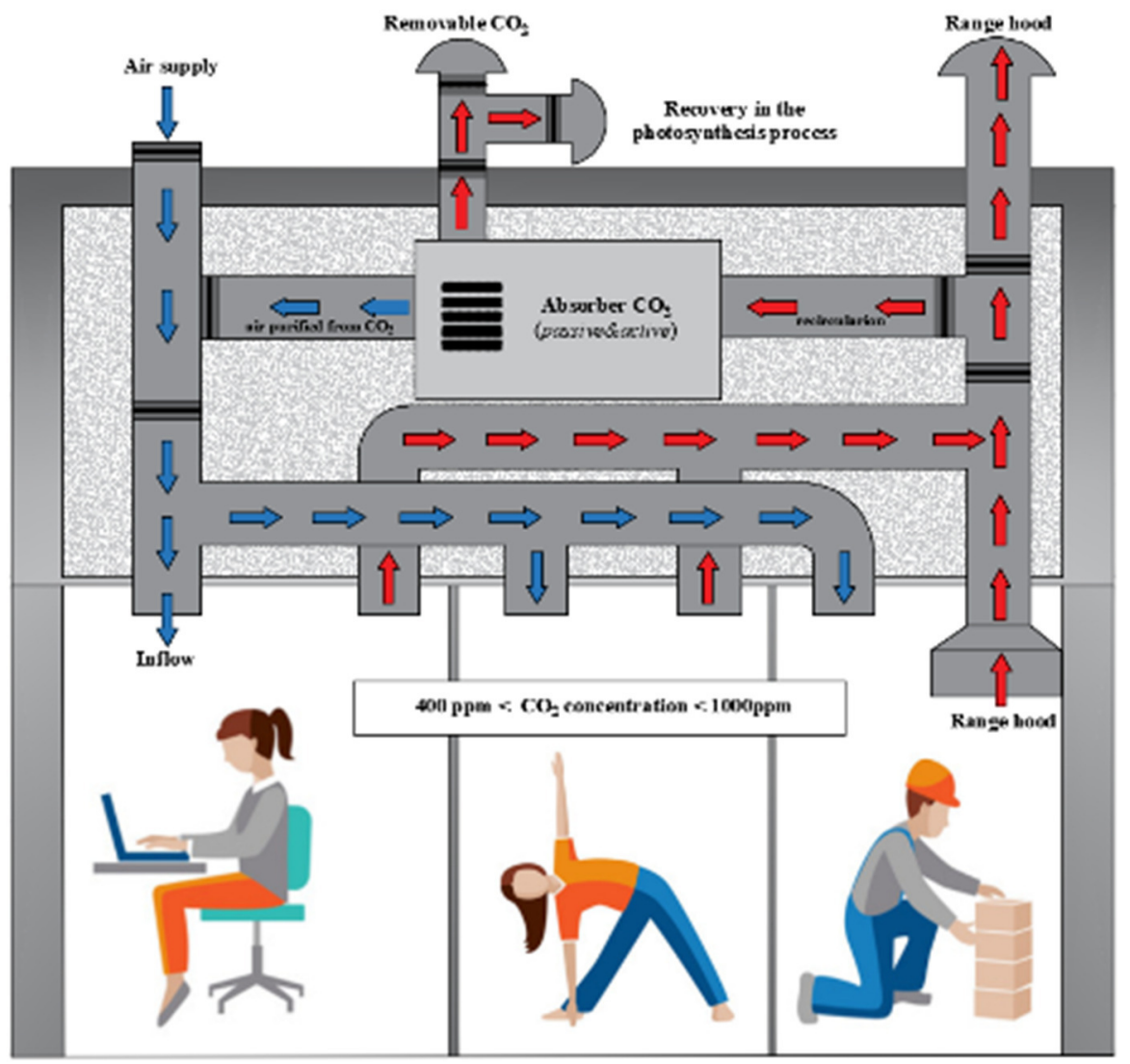

Figure 11 - Possible construction scheme of a comprehensive adaptive air supply system with additional inflow and exhaust ducts arrangement with shut-off valves, simultaneous purification of regenerative air streams by passive (active) adsorbers and implementation of continuous monitoring and object management systems

\section{Conclusions}

According to the developed methodology and using electronic devices for measuring the carbon dioxide $\left(\mathrm{CO}_{2}\right)$ content in the air and using special laboratory facilities set on the school classroom example, the following was studied:

a) the variety of interactions between the external environment and the subsystem - classroom air;

b) internal objects constituents activity (present pupils, plants, adsorbing surfaces of structures elements and interior) to emit-absorb $\mathrm{CO}_{2}$ depending on the conditions and variation of dominant factors action; c) their manifestation and influence on the forming the air mass composition and content, and therefore the classroom internal microclimate, which quality directly affects the health and working efficiency of the modern people.

The study is aimed at monitoring and real assessment of contribution, clarifying the ratio of the $\mathrm{CO}_{2}$ emission volumes by each source in the overall mass-gas manifestation and search for innovative solutions to develop adaptive systems for stabilization and maintenance of microclimate in similar objects. 


\section{References}

1. ISO 16000-1: 2004. Indoor air - Part 1: General aspects of sasampling strategy.

2. Наумов, А.Л., Капко, Д.В. (2011). Системы адаптивной вентиляции: перспективные направления развития. ABOK. 7. 30-36.

3. Шульте, Р., Бридгес, Б., Гримсруд, Д. (2005). Непрерывный мониторинг качества внутреннего воздуха в школьных зданиях. $A B O K, 8$. 29-35.

4. Balikhin, I.L., Berestenko, V.I., Domashnev, I.A. et al. Photo-catalytic element for cleaning and disinfecting of air and water and the method of its manufacturing. Patent RU 2647839 C2. Moscow.

5. Dryuchko, O., Storozhenko, D., Vigdorchik, A., Bunyakina, N., Ivanytska, I., Kytayhora, K., Khanyukov, V. (2019) Features of transformations in REE-containing systems of nitrate precursors in preparatory processes of formation of multifunctional oxide materials. Molecular Crystals and Liquid Crystals, 672(1), 199-214.

https://doi.org/10.1080/15421406.2018.1542066

6. Zhang Xianhong, Zhang Anji, Zhang Haiyin et al. Preparation and application of a hydrophilic self-cleaning coating with photocatalytic activity. Patent CN 102382490 A. China.

7. Lachhaba, F., Bakhouyaa, M., Ouladsinea, R. \& Essaaidi, M. (2018). Towards an Intelligent Approach for Ventilation Systems Control using IoT and Big Data Technologies. Procedia Computer Science, 130, 926-931.

8. ANSI/ASHRAE Standard 62.1-2007. Ventilation for Acceptable Air Quality.

9. EN 13779: 2007. Ventilation for non-residential buildings - performance requirements for ventilation and roomconditioning systems.

10. EN 15251:2007. Indoor environmental input parameters for design and assessment of energy performance of buildings addressing indoor air quality, thermal environment, lighting and acoustics.

11. ДСТУ Б ЕN 15251:2011. (2012). Розрахункові параметри мікроклімату приміщень для проектування та оиінки енергетичних характеристик будівель по відношенню до якості повітря, теплового комфорту, освітлення та акустики (EN 15251:2007, IDT). Київ, Мінрегіон України.

12. Литвинова, Н.А. (2019). Очистка воздуха помещений от загрязняющих веществ с использованием воздушного приточного клапана с фотокаталитическим фильтром. Экологическая безопасность строчтельства и городского хозяйства, 3. 81-87.

https://doi.org/10.24411/1816-1863-2019-13081

13. Рымаров, А. Г. (2016). Исследование применения воздушных клапанов в квартире жилого здания в холодный период. Сантехника, отопление, кондиционирование. Режим доступа: https://www.c-o-k.ru

14. Shikai Zhang, Anlan Ding, Xiuguo Zou et alt. (2019). Simulation Analysis of a Ventilation System in a Smart Chamber Based on Computational. Atmosphere, 315(10), $1-17$

15. Мастеров, И.В. (2005). Вентилящия. Санкт-Петербург: ДИЛЯ.

16. Литвинова, Н.А. (2019). Вентиляция и качество воздуха в зданиях городской среды. Москва: Инфра-М.

17. Monk, B. (2019). Air Quality in Airports. $A B O K, 4$, 6874.

18. Смагин, А.В. (2015). Кинетическая оценка газообмена между почвой и атмосферой камерно-статическим методом. Почвоведение, 7, 824-831.

https://doi.org/10.7868/S0032180X15070102
1. ISO 16000-1: 2004. Indoor air - Part 1: General aspects of sampling strategy.

2. Naumov, A.L., Kapko, D.V. (2011). Adaptive ventilation systems: promising areas of development. $A B O K .7 .30-36$.

3. Schulte, R., Bridges, B., Grimsrud, D. (2005). Continuous monitoring of indoor air quality in school buildings. ABOK. 8. 29-35.

4. Balikhin, I.L., Berestenko, V.I., Domashnev, I.A. et al. Photo-catalytic element for cleaning and disinfecting of air and water and the method of its manufacturing. Patent RU 2647839 C2. Moscow.

5. Dryuchko, O., Storozhenko, D., Vigdorchik, A., Bunyakina, N., Ivanytska, I., Kytayhora, K., Khanyukov, V. (2019). Features of transformations in REE-containing systems of nitrate precursors in preparatory processes of formation of multifunctional oxide materials. Molecular Crystals and Liquid Crystals, 672(1), 199-214.

https://doi.org/10.1080/15421406.2018.1542066

6. Zhang Xianhong, Zhang Anji, Zhang Haiyin et al. Preparation and application of a hydrophilic self-cleaning coating with photocatalytic activity. Patent CN 102382490 A. China.

7. Lachhaba, F., Bakhouyaa, M., Ouladsinea, R. \& Essaaidi, M. (2018). Towards an Intelligent Approach for Ventilation Systems Control using IoT and Big Data Technologies. Procedia Computer Science, 130, 926-931.

8. ANSI/ASHRAE Standard 62.1-2007. Ventilation for Acceptable Air Quality.

9. EN 13779: 2007. Ventilation for non-residential buildings - performance requirements for ventilation and roomconditioning systems.

10. EN 15251:2007. Indoor environmental input parameters for design and assessment of energy performance of buildings addressing indoor air quality, thermal environment, lighting and acoustics.

11. DSTU B EN 15251: 2011. (2012). Estimated microclimate parameters of premises for the design and evaluation of the energy performance of buildings in relation to air quality, thermal comfort, lighting and acoustics (EN 15251: 2007, IDT). Kyiv: Ministry of Regional Development of Ukraine.

12. Litvinova, N.A. (2019). Purification of indoor air from pollutants using an air supply valve with a photocatalytic filter. Environmental safety of construction and urban economy, 3. 81-87.

https://doi.org/10.24411/1816-1863-2019-13081

13. Rymarov, A.G. (2016). A study of the use of air valves in an apartment in a residential building in the cold season. Plumbing, heating, air conditioning. Access Mode: https://www.c-o-k.ru

14. Shikai Zhang, Anlan Ding, Xiuguo Zou et alt. (2019). Simulation Analysis of a Ventilation System in a Smart Chamber Based on Computational. Atmosphere, 315(10), $1-17$.

15. Masters, I.V. (2005). Ventilation. St. Petersburg: DILIA.

16. Litvinova, N.A. (2019). Ventilation and air quality in urban buildings. Moscow: Infra-M.

17. Monk, B. (2019). Air Quality in Airports. $A B O K, 4,68-$ 74.

18. Smagin, A.V. (2015). Kinetic assessment of gas exchange between soil and atmosphere using the chamber-static method. Soil science, 7, 824-831.

https://doi.org/10.7868/S0032180X15070102 
19. Muneer, S., Jeong Kim, E., Suk Park, J. et alt. (2014). Influence of Green, Red and Blue Light Emitting Diodes on Multiprotein Complex Proteins and Photosynthetic Activity under Different Light Intensities in Lettuce Leaves (Lactuca sativa L.). International Journal of Molecular Sciences, 15(3), 4657-4670.

https://doi.org/10.3390/ijms15034657

20. Kang, J.H., Krishnkumar, S., Sua Atulba, S.L. et al. (2013). Light intensity and photoperiod influence the growth and development of hydroponically grown leaf lettuce in a closed-type plant factory system. Horticulture, Environment, and Biotechnology, 54, 501-509.

21. Sun, J.D., Nishio, J.N., Vogelmann, T.C. (1998). Green light drives $\mathrm{CO}_{2}$ fixation deep withinleaves. Plant Cell Physiol, 39, 1020-1026.

22. Родионов, И.А., Силюков, О.И., Зверева, И.А. (2012). Исследование фотокаталитической активности слоистых оксидов $\mathrm{ALnTiO}_{4}(\mathrm{~A}=\mathrm{Na}, \mathrm{Li}, \mathrm{H})$. Журнал общей химии, 4, 548-555.

23. Dryuchko, O.G., Storozhenko, D.O., Bunyakina, N.V., Ivanytska, I.O., Khanyukov, V.O., Kytayhora, K.O. (2019). Formation of multifunctional nano-layered oxide REE-containing materials using nitrate precursors. Academic journal. Series: Industrial Machine Building, Civil Engineering, 1(52), 216-225.

https://doi.org/10.26906/znp.2019.52.1701
19. Muneer, S., Jeong Kim, E., Suk Park, J. et alt. (2014). Influence of Green, Red and Blue Light Emitting Diodes on Multiprotein Complex Proteins and Photosynthetic Activity under Different Light Intensities in Lettuce Leaves (Lactuca sativa L.). International Journal of Molecular Sciences, 15(3), 4657-4670.

https://doi.org/10.3390/ijms15034657

20. Kang, J.H., Krishnkumar, S., Sua Atulba, S.L. et al. (2013). Light intensity and photoperiod influence the growth and development of hydroponically grown leaf lettuce in a closed-type plant factory system. Horticulture, Environment, and Biotechnology, 54, 501-509.

21. Sun, J.D., Nishio, J.N., Vogelmann, T.C. (1998). Green light drives $\mathrm{CO}_{2}$ fixation deep withinleaves. Plant Cell Physiol, 39, 1020-1026.

22. Rodionov, I.A., Silyukov, O.I., Zvereva, I.A. (2012). Investigation of the photocatalytic activity of layered oxides ALnTiO4 (A = Na, Li, H). Journal of General Chemistry, 4, 548-555.

23. Dryuchko, O.G., Storozhenko, D.O., Bunyakina, N.V., Ivanytska, I.O., Khanyukov, V.O., Kytayhora, K.O. (2019). Formation of multifunctional nano-layered oxide REE-containing materials using nitrate precursors. Academic journal. Series: Industrial Machine Building, Civil Engineering, 1(52), 216-225.

https://doi.org/10.26906/znp.2019.52.1701 